\title{
HVMANITAS
}

\section{Sonho e persuasão na épica homérica}
Autor(es):
Marques, Susana Hora

Publicado por: Imprensa da Universidade de Coimbra

URL persistente:

URI:http://hdl.handle.net/10316.2/35056

DOI:

DOI:http://dx.doi.org/10.14195/2183-1718_66_2

Accessed : $\quad$ 26-Apr-2023 12:53:01

A navegação consulta e descarregamento dos títulos inseridos nas Bibliotecas Digitais UC Digitalis, UC Pombalina e UC Impactum, pressupõem a aceitação plena e sem reservas dos Termos e Condições de Uso destas Bibliotecas Digitais, disponíveis em https://digitalis.uc.pt/pt-pt/termos.

Conforme exposto nos referidos Termos e Condições de Uso, o descarregamento de títulos de acesso restrito requer uma licença válida de autorização devendo o utilizador aceder ao(s) documento(s) a partir de um endereço de IP da instituição detentora da supramencionada licença.

Ao utilizador é apenas permitido o descarregamento para uso pessoal, pelo que o emprego do(s) título(s) descarregado(s) para outro fim, designadamente comercial, carece de autorização do respetivo autor ou editor da obra.

Na medida em que todas as obras da UC Digitalis se encontram protegidas pelo Código do Direito de Autor e Direitos Conexos e demais legislação aplicável, toda a cópia, parcial ou total, deste documento, nos casos em que é legalmente admitida, deverá conter ou fazer-se acompanhar por este aviso. 
humanitas

Vol. LXVI

2014

IMPRENSA DA UNIVERSIDADE DE COIMBRA

COIMBRA UNIVERSITY PRESS 


\title{
Sonho e Persuasão na Épica Homérica
}

\section{DREAM AND PERSUASION IN HOMERIC POETRY}

\author{
Susana Hora Marques \\ Centro de Estudos Clássicos e Humanísticos da Universidade de Coimbra \\ smp@fl.uc.pt
}

\section{Resumo}

A épica homérica evidencia de forma reiterada o empenho divino em controlar a acção do homem, propósito que se reflecte também nos sonhos que descreve. O presente contributo pretende no entanto destacar como o próprio mundo divino e os sonhos épicos em geral se acomodam às exigências da Persuasão.

Palavras-chave: épica homérica, sonho, persuasão

\footnotetext{
Abstract:

Homeric epic continuously shows the divinities' determination in controlling human action; the dreams described in the Homeric Poems fit in with this scenario. The present article intends, however, to focus on how the divine world and epic dreams in general are dependent on the demands of Persuasion.

Keywords: Greek epic, dream, persuasion

Não foi a eloquência que nasceu dos preceitos, mas os preceitos que nasceram da eloquêncial.

A voz autorizada de Cícero legitima o reconhecimento de elementos da retórica em discursos anteriores à primeira codificação das regras daquela ciência por Córax e Tísias, no século $\mathrm{V}$ a. C., como se sabe.

$1 \quad$ Cic., De Or. 1. 32. 146.
} 
A existência de uma pré-retórica, ainda que controversa ${ }^{2}$, parece fundamentada pelos Poemas Homéricos, recheados de poderosos discursos com intuito persuasivo, e que se servem com frequência de figuras e de técnicas retóricas para convencer o(s) receptor(es) ${ }^{3}$. Curiosamente, num universo em que as acções humanas se afiguram controladas pela vontade dos deuses, as próprias divindades recorrem a peithô para instigar os mortais a uma conduta determinada - peithô 'converte-se no nome genérico da estratégia que suscita o desejo"4. O mundo onírico da épica grega, sem assumir uma expressão retórica formal, no confronto de ideias e teses, adopta com frequência uma táctica relacionada com o estímulo a emoções, de uma forma mais geral e difusa. De facto, os sonhos homéricos, de origem divina e via de regra formulados numa linguagem clara, que pretende esclarecer ou resolver determinadas situações, evidenciam um cuidado particular na escolha da figura da aparição onírica, da mensagem a transmitir e do próprio sonhador, na mira de uma desejada eficácia persuasiva. Tal procedimento, sem enquadrar, naturalmente, a persuasão homérica numa disciplina que apenas surge em data posterior, mostra-se consonante com a tese aristotélica de que as provas de peithô residem no orador, no discurso e na disposição do ouvinte (cf. $R h$. 1356a).

No que toca à figura que recebe as visões sonhadas, ela tem em geral uma condição social de relevo, que lhe confere à partida uma posição preferencial para a comunicação dos acontecimentos revelados - poderosa, tem capacidade para intervir em função das indicações anunciadas, além de que o seu estatuto parece conceder às experiências oníricas, se estas contêm implicações públicas, ascendente perante os outros homens. Nesta perspectiva se pode entender o comentário do prudente Nestor, depois de ter ouvido Agamémnon contar o seu sonho na assembleia de anciãos que convocara (cf. Il. 2. 79-83): o velho rei de Pilos apoiou que se reunissem os Gregos para o combate, porque essa orientação fora dada por um sonho divino ao Atrida, o mais nobre dos Aqueus. E acrescentou ainda que, se a mesma visão tivesse sido sonhada por outro homem qualquer, seria

2 A este propósito, cf. Rocha Pereira 1997: 40.

3 De resto, a conhecida referência de Fénix aos propósitos da educação que proporcionara a Aquiles é já bem ilustrativa da preocupação com a ars bene dicendi (cf. Il. 9. 442-443). Sobre a existência de uma proto-retórica nos Poemas Homéricos, cf. López Eire 1997 e López Eire 2002.

4 Cf. V. Pirenne-Delforge 1991. 
considerada falsa e suscitaria maior desconfiança, ideia sublinhada pelo emprego expressivo de pseudos no início do verso $81^{5}$.

A personagem onírica, por seu turno, é deliberadamente forjada pelos deuses, tendo em conta a pessoa do sonhador. Deste modo, é significativo, em termos de credibilidade e de sentido do sonho de Agamémnon, por exemplo, que seja a imagem do experiente Nestor, a quem entre os anciãos mais honrava Agamémnon (Il. 2. 21) ${ }^{6}$, a transmitir-lhe uma mensagem vinculadora de ordens de ataque contra o inimigo troiano (cf. Il. 2. 20 sqq.) ${ }^{7}$.

A visão de Agamémnon sobrevém em plena campanha militar, após o diferendo que o opôs a Aquiles e que afastou o filho de Tétis da peleja, e reproduz instruções bélicas interpretadas pelo receptor como indiciadoras de um triunfo almejado sobre o inimigo: a ausência do Pelida de um combate vitorioso para os Helenos ampliaria o júbilo do orgulhoso Atrida. Designado porém, de modo sugestivo, como nocivo (Il. 2. 6), o sonho repete, em discurso directo, as deliberações de Zeus ${ }^{8}$, propositadamente enganadoras, com o intuito manifesto de favorecer Aquiles e de o honrar. Incapaz de dormir enquanto repousavam todos os homens e os restantes deuses, o soberano divino, preocupado com as promessas feitas a Tétis, decide enviar o sonho à tenda do Atrida, para estimular o herói a armar os Aqueus contra os Troianos. A vontade de Zeus não se traduz contudo numa mera ordem, mas faz-se acompanhar de um argumento muito sedutor para o chefe grego: a garantia da tomada de Tróia, questão em que finalmente os deuses haviam concordado (Il. 2. 12 sqq.). Falacioso, o sonho ilude o herói com o seu discurso convincente, num tom apelativo, traduzido por elementos como o recurso à segunda pessoa, ao vocativo ou à frase de tipo imperativo (cf. Il. 2.23 sqq.): as consequências resultantes da mensagem transmitida seriam honrosas para o receptor, a nível pessoal e, em particular, a nível público. Agamémnon, confiante, adere com prontidão às orientações divinas, como era comum entre os heróis homéricos; todavia, o poeta não deixa de sublinhar a insensatez do seu pensamento ambicioso de que seria

5 Sobre a utilização falaciosa do sonho, nomeadamente por Ulisses dos mil artifícios, cf. infra.

6 As traduções da Ilíada são retiradas de Lourenço 2005.

7 Sabemos todavia que por trás dos traços visíveis do rei de Pilos está de facto um mensageiro dos deuses, que se identifica desse modo perante o sonhador (v. 26) - cf. a usual dependência humana do mundo divino na épica homérica.

8 A propósito da distinção entre o discurso omnisciente do narrador e o das figuras intervenientes na acção dos Poemas Homéricos, cf. Griffin 1986. 
efectivamente capaz de tomar a cidade de Príamo sem a ajuda de Aquiles (cf. Il. 2.35 sqq.) - no comentário do narrador, é perceptível a noção de que Agamémnon era merecedor de punição pelo comportamento que tivera. Ao acordar, após a partida da aparição, de imediato o chefe da expedição contra Ílion se dispõe a agir em conformidade com as suas indicações, sem questionar a veracidade da mensagem. Nesse sentido, convoca o Conselho dos anciãos e conta aos chefes dos Aqueus, experientes e sábios, o sonho que tivera, justificativo do retorno à refrega, como reconhece o velho Nestor (Il. 2. 76 sqq.). Revela-lhes porém que mentiria ao exército, para o pôr à prova, incitando os seus homens ao regresso à pátria amada, ainda que sem terem subjugado Tróia (cf. Il. 2. 50 sqq.) - ironicamente, o Atrida, receptor de um sonho enganador, recorre também ao dolo como artifício persuasivo, numa atitude sugestiva de que a falácia pode constituir-se como argumento poderoso, manipuladora do 'outro' graças à força inegável do logos. De facto, o intuito do sonho é paralelo ao da proposta de Agamémnon: conduzir os receptores a uma actuação específica. Desgastados após tantos anos de dura guerra, os Helenos facilmente se deixam entusiasmar pelas palavras do Atrida, esquecendo de forma vergonhosa acordos e juramentos (Il. 2. 339) de outrora, numa predisposição que impediria a concretização dos intentos do sonho - apenas o discurso convincente do hábil Ulisses é capaz de conservar os Argivos em Tróia (Il. 2. 284 sqq.), dispostos a continuar a guerra, e de dar cumprimento à visão onírica. Neste jogo de verdade e mentira, destaca-se o poder da palavra ao serviço de intenções distintas - no sonho, como na realidade, o discurso instiga os receptores a tomar decisões aparentemente favorecedoras dos objectivos do orador.

O sonho funciona aqui como um agente da justiça divina ${ }^{9}$, que pune o Atrida pelo seu comportamento arrogante face ao Pelida: de modo hábil, Zeus encontra uma forma de lhe mostrar que ele não era superior ao filho de Tétis, de quem afinal precisaria para conquistar Tróia. Como é sabido, a punição não se revela desastrosa para a empresa que o rei de Argos comandava, nem mesmo para ele próprio enquanto chefe militar, já que mais tarde, com o apoio de Aquiles, conseguiria tomar vitoriosamente a cidade de Príamo, em sintonia com a determinação dos deuses.

9 Cf. Hdt. 12-18: os sonhos de Xerxes e de Artabano sublinham também a necessidade de punir os excessos do monarca persa. Cf. ainda as experiências oníricas de Clitemnestra, nas Coéforas de Ésquilo e na Electra sofocliana, ilustrativas de que a justiça supra-humana não deixa impunes os actos reprováveis dos mortais. 
Na experiência sonhada de Agamémnon, a presença de peithô é notória, não apenas na escolha da figura da aparição, mas também na própria mensagem, que deita a mão à ambição do receptor, para o instigar à eficácia da acção pretendida, recorrendo a um discurso eloquente de força inegável. As estratégias persuasivas evidenciam-se ainda no apelo subtil ao código heróico de honra, uma vez que o Atrida é chamado às suas responsabilidades na qualidade de chefe supremo dos Aqueus (cf. Il. 2. 24-25 e 28: Não deve dormir toda a noite o homem aconselhado, a quem está confiada a hoste... (...) Manda armar depressa os Aqueus de longos cabelos...). Nos sinais divinos, como na realidade, a persuasão intensifica os propósitos do orador.

De modo paralelo, também na Odisseia 6.15 sqq., Atena se coloca durante a noite sobre a cabeça da princesa Nausícaa, tomando o aspecto da filha de Dimante, uma jovem companheira pela qual a descendente de Alcínoo tinha grande estima. É sabido que a deusa de olhos $\operatorname{garços}^{10}$ protegia Ulisses no seu regresso a Ítaca, e é precisamente a pensar num meio de ajudar o herói, então adormecido na praia da Feácia, que inspira o sonho à donzela, no intuito de possibilitar um encontro entre ambos ${ }^{11}$. Assim, a visão sonhada revela-se, em simultâneo, como um astucioso estímulo pessoal às núpcias de uma princesa em idade casadoira e, por outro lado, como o motor para uma intervenção necessária ao retorno de Ulisses ao seu reino. A jovem figura onírica, decerto com ambições semelhantes às de Nausícaa, dirige-se à princesa, numa espécie de proémio ${ }^{12}$, questionando-a, e expõe o tema a tratar, ao censurá-la por não ter as roupas resplandecentes numa altura em que se evidenciava a possibilidade de casar $\left(O d .6\right.$. 34-35) ${ }^{13}$. Nesse sentido, argumenta com habilidade, aludindo a supostos pretendentes, e incita-a a ir lavar ao rio, num tom reiteradamente exortativo (Od. 6. 31, 36), adequado a um estilo retórico. A aparição, dotada de mobilidade, dispõe-se inclusive a acompanhar a sonhadora, assegurando com a sua disponibilidade e apoio ora a captatio beneuolentiae da receptora onírica, ora o sucesso das determinações nocturnas. É compreensível que a aspiração ao casamento constitua motivo dos pensamentos da princesa, na sua condição de donzela: o sonho e os desejos da receptora mostram-se coincidentes e permitem que

10 As traduções da Odisseia são retiradas de Lourenço 2006.

11 Cf. v. 14, onde se explicitam as intenções de Atena.

12 Cf. a disposição do discurso retórico em 3/ 4 partes fundamentais: proémio, narração, argumentação e epílogo.

13 Segundo Aristóteles, Rh. 1415a, a censura é um dos elementos susceptíveis de constar do proémio de um discurso epidíctico. 
ela actue em conformidade com os desígnios manifestados pelas hábeis palavras premeditadas por Atena. Uma vez mais, a entidade onírica é inspiradora de uma missão, procurando interferir de um modo convincente nas emoções da princesa, desta feita, sobremodo pessoais. Nausícaa acorda, admirada com uma visão que correspondia aos seus anseios, e apressa-se a pedir ao pai que lhe mande aparelhar um carro de mulas para ir lavar a roupa ao rio, seguindo as indicações do epílogo do discurso onírico, sem as questionar. A filha de Alcínoo parte ao encontro de Ulisses, sem o saber, numa viagem unicamente determinada pelas orientações sonhadas, tradutoras de uma vontade divina específica: é clara a utilidade funcional desta experiência que procura resolver a situação do filho de Laertes, bem como o poder de peithô enquanto garante da eficácia de uma actuação determinada, que explora a psicologia da sonhadora, jovem e donzela, para a instigar à consecução da atitude pretendida.

Igualmente sintomática da importância atribuída à persuasão pelos sonhos homéricos é a interpelação da psychê de Pátroclo a Aquiles, em nome da philia que os mantivera unidos em vida (Il. 23. 62 sqq.). Na verdade, a figura de Pátroclo aparece em sonhos ao Pelida, o grande amigo que chorava ainda a sua morte, a reclamar sepultura: agora não estão em causa ambições dos receptores, mas a noção de philia, que impele o filho de Tétis a uma acção devida. O mesmo Aquiles que, no canto nono da Ilíada, não se deixara convencer por três discursos sucessivos, de clara índole retórica, aos quais se associaram presentes sedutores, deixa-se no entanto persuadir pelo valor da amizade.

Os pormenores descritivos da imagem onírica, pouco usuais na épica, evidenciam a presença, diante dos olhos de Aquiles, de uma figura em tudo maravilhosamente semelhante à do companheiro com quem estabelecera profundos laços afectivos (Il. 23. 65-68), permitindo assim um prolongamento visível da relação que os unia. A aparição onírica inicia de modo convencional o seu discurso retórico, interpelando Aquiles adormecido e referindo o assunto a tratar: a necessidade de receber sepultura. A intervenção continua, com uma argumentação fundamentadora da pretensão de Pátroclo, que recorda ao amigo o facto de terem sido criados e educados em conjunto, bem como de estarem ligados por vínculos de hospitalidade (Il. 23. 83-90), pelo que também na morte deveriam ficar próximos um do outro (Il. 23. 91-92). As lembranças do herói, a antítese morte/ vida, presente/ passado, os vocativos frequentes, o emprego expressivo de dá-me a tua mão, no v. 75 , a insistência em pronomes da primeira e da segunda pessoas, o recurso 
às lágrimas, evocativas de humanidade num universo dominado pela guerra, são elementos sugestivos do tom apelativo do discurso, capaz de influenciar o receptor. Ao concentrar a atenção na relação de ambos em vida, Pátroclo pretende resolver a sua situação de defunto insepulto, como acontecerá efectivamente depois de o sonhador acordar. Por outro lado, visa manter no além a mesma afinidade com Aquiles, como sublinham, no epílogo, as palavras derradeiras da psychê, intensificadoras da vontade de encaminhar Aquiles numa direcção propícia. Numa sentida manifestação exterior de philia, o filho de Tétis procura abraçar o amigo; no entanto, a imaterialidade da sua imagem não o deixa consumar o propósito e vale-lhe uma conclusão famosa sobre a existência depois da morte (Il. 23. 97-107). A tentativa que o herói faz de interpelar a aparição é frustrada pelo esvaecimento da psyche de Pátroclo: o sonho não se deixa consultar; a sua pretensão é convencer o receptor a uma atitude determinada.

Para lá das experiências oníricas efectivamente ocorridas, nos Poemas Homéricos acontece ainda o recurso ao fingimento do sonho com intuito persuasivo, por uma figura que quer servir os seus próprios interesses: Ulisses, o homem de mil ardis, que, a par de elementos como o vinho ${ }^{14}$ ou o disfarce ${ }^{15}$, usa a visão sonhada como instrumento de engano (Od. 14. 462 sqq.). Disfarçado de mendigo na cabana do porqueiro Eumeu, e sem revelar a sua identidade, Ulisses decide inventar uma história para convencer o seu hospedeiro a arranjar-lhe agasalhos para a noite fria e chuvosa que se aproximava, ao mesmo tempo que experimenta a sua generosidade: hábil, o filho de Laertes encontra uma solução para resolver uma situação iminente de frio ${ }^{16}$. No seu relato, faz alusão a um sonho divino ocorrido durante o sono $^{17}$, prevendo a influência que ele teria sobre quem o escutasse - decerto inspiraria à acção, a uma resposta positiva à mensagem transmitida, como era habitual entre os heróis épicos, o que parece pressupor a existência de um código do sonho implicitamente conhecido e respeitado por todos.

14 Cf. Od. 9.345 sqq.: Ulisses embriaga o Ciclope, engana-o e consegue escapar-lhe. Em $V .181$ sqq., Aristófanes parodia este episódio famoso.

15 Cf. Od.13. 397 sqq.: segundo as indicações de Atena, Ulisses toma o aspecto de um mendigo, para poder concretizar a sua vingança.

16 É recorrente o recurso ao paradeigma como argumento de persuasão nos Poemas Homéricos (e.g. 1.261 sqq., 9. 529 sqq.), uma técnica muito usada pela Retórica, como é sabido.

17 No que diz respeito a questões relacionadas com a interpolação do verso 495, no qual aparece a menção ao sonho, cf. W. B. Stanford 1987-1991, comm. ad. loc. A edição de Oxford, seguida pelo presente estudo, dá o verso como autêntico. 
Com efeito, os sonhos homéricos obedecem regra geral a um mesmo esquema padrão (ou a partes desse modelo): à noite, durante o sono, uma aparição surge convencionalmente sobre a cabeça do sonhador ${ }^{18}$, dirige-lhe algumas palavras ${ }^{19}$, censurando-o por estar a dormir e dando-lhe uma ordem ou uma indicação aparentemente clara sobre o futuro, e depois desaparece; o receptor da visão sonhada acorda e reage de modo positivo à mensagem recebida, seguindo as suas recomendações. Esta convenção do sonho nos Poemas Homéricos testemunha o facto de ele ser personificado e exterior ao sonhador, que percebe habitualmente o seu movimento de chegada e de partida, em geral rápida.

O astucioso herói conta como outrora, durante a guerra de Tróia, Ulisses fora capaz de lhe arranjar um agasalho, numa noite gélida: num discurso apelativo, marcado por elementos como o vocativo ou o recurso à $2^{\mathrm{a}}$ pessoa (cf. Od. 14. 495 sqq.), depois de aludir a um sonho que lhe sobreviera, o filho de Laertes manifestara vontade de que algum dos guerreiros que descansavam, como ele, nas proximidades das muralhas de Ílion, fosse buscar reforços junto de Agamémnon. O discurso instigou Toas a partir, depois de atirar a sua capa para o chão. Nesta história, a referência à experiência onírica conduz efectivamente à actuação decidida do guerreiro, consciente de uma missão a cumprir, e à satisfação, por outro lado, dos intentos de Ulisses e do seu pressuposto "companheiro" que, mais aconchegado, conseguiu finalmente adormecer (Od. 14. 501-502). De modo significativo, porquanto as palavras derradeiras são em geral as que permanecem melhor na memória dos interlocutores ${ }^{20}$, a intervenção de Ulisses-mendigo termina numa combinação expressiva entre os tons volitivo e condicional, que apela com subtileza à amabilidade do seu hospedeiro (Od. 14. 504 sqq.).

A ficção do sonho permite ao filho de Laertes alcançar os seus propósitos, dentro do relato inventado, mas também fora dele, já que Eumeu, compreendendo a mensagem, afirmou que não lhe faltariam agasalhos nessa noite (Od. 14. 508 sqq.). Karp ${ }^{21}$ estabelece uma interessante comparação entre a perícia usual de Ulisses para 'fazer o que é falso parecer verdadeiro'

18 Cf. o emprego recorrente da expressão formular postou-se junto à sua cabeça (Il. 2. 20, 23. 68, 24. 682), a remeter para o carácter estático e estereotipado do sonho - o herói vê um quadro.

19 O discurso habitual da personagem onírica é introduzido por fórmulas como assim lhe falou (Il. 2. 22).

20 Cf. Arist., Rh. 1415a.

$211977,249$. 
e a capacidade retórica de converter um argumento mais fraco no mais forte, muito desenvolvida pelos ensinamentos sofísticos, como se sabe ${ }^{22}$.

As visões oníricas seleccionadas tornam patente a presença reiterada de peithô enquanto meio favorecedor duma atitude determinada dos receptores: a persuasão evidencia-se como um agente privilegiado no contacto do universo divino com os mortais, facto a que decerto não é alheia a semelhança de ânimo e de reacções entre a divindade e os efémeros. De modo eficaz, o sonho adequa a figura onírica ${ }^{23}$ e o discurso ${ }^{24}$ aos intentos e às emoções particulares do receptor que visa manipular, antecipando, em certa medida, a prática retórica posterior. Não se trata contudo da exploração de estratégias argumentativas instigadoras duma mudança de opinião ou de atitude nos interlocutores, mas sobretudo de os conduzir a um comportamento específico, num momento particular e tendo em conta a oportunidade do contexto narrativo, a nível da acção anterior e subsequente ao sonho. Embora a Ilíada e a Odisseia não se refiram a factores de ordem psicológica, há um pressuposto dessa natureza na estratégia relativa à forma tomada pela visão e aos argumentos evocados para o fim a atingir, ou seja, o próprio mundo divino, que se revela habitualmente controlador dos actos humanos, sente necessidade de se acomodar às exigências de peithô e de captar desde logo a benevolência dos interlocutores. Além disso, os discursos das aparições sonhadas afiguram-se próximos da oratória posterior, ora pelo tom exortativo que empregam, ora pelo uso reiterado da apóstrofe, ora pelo recurso ao exemplum (cf. história de Ulisses, no Canto catorze da Odisseia) ou à recordação do passado, ora pela promessa de proveito futuro.

Muito dependentes da divindade e de códigos de valores ancestrais, os sonhadores não contrapõem argumentos às palavras das aparições, cujos desígnios se apressam a cumprir, sem oferecer resistência, seja pela origem sobre-humana das experiências sonhadas, seja também pela correspondência que encontram entre o caminho sugerido e as aspirações/ convicções pessoais. Os sonhos, prerrogativa divina, não se deixam consultar pelos

22 A este propósito, cf. Guthrie 1971, em particular o capítulo VII, Romilly 1988, sobretudo os capítulos IV e V.

Platão, no Górgias e no Fedro, acentua todavia a importância de alicerçar a retórica na verdade.

23 Cf. Nestor, ancião venerável, a filha de Dimante, uma jovem companheira, Pátroclo, um grande amigo, Ulisses, um herói com provas dadas na arte de bem falar.

24 Cf. alusão a uma conquista desejada, a núpcias almejadas, a uma amizade para além da morte, a uma história exemplar. 
efémeros, pelo que não há lugar para o debate, para a defesa de pontos de vista distintos, muito habitual na retórica política e forense, como é sabido. No caso das visões sonhadas, a censura convencional consiste sobretudo no facto de o sonhador estar a dormir, razão sem margem para ser rebatida. No caso particular da experiência de Nausícaa, a advertência prende-se com a argumentação do próprio sonho, i. e., com a distracção evidenciada pela jovem em relação à resplandecência das suas vestes. Não há necessidade de a aparição onírica multiplicar argumentos quando os receptores aderem às pretensões expostas, sem discussão e até com certo prazer. Tão pouco são necessários presentes sedutores, uma outra forma de actuação de peithô, por norma muito convincente. Não está em jogo o litígio pelo triunfo de uma causa, ou mesmo a alteração de um comportamento, mas a intensificação de um propósito divino através de um expediente sancionado e utilizado com sucesso pelos próprios deuses, à semelhança dos humanos. A execução das indicações sonhadas fundamenta-se na confiança dos receptores no discurso persuasivo assumido pela autoridade onírica.

Como observa com oportunidade Carey ${ }^{25}$, a retórica clássica 'sistematiza uma prática já existente, dado que o apelo emocional não é produto nem da democracia ateniense, nem dos ensinamentos sofísticos'. Num reino que constitui uma projecção da vida, o do sonho, a persuasão tem lugar garantido, porquanto reflexo inequívoco das relações humanas, norteadas por valores que regem igualmente a convivência dos imortais e que se manifestam mesmo nos processos de recurso ou de substituição, como as experiências oníricas.

\section{Bibliografia}

Allen, T. W. and Monro, D. B. edd. (reimp. 1962-1963). Homeri opera, I-II. Oxford. Allen, T. W. ed. (reimp. 1963-1965). Homeri opera, III-IV. Oxford.

Lourenço; F. (2005, $2^{\mathrm{a}}$ ed.). Homero. Ilíada. Lisboa.

Lourenço, F. (2006, 6 a ed.) Homero. Odisseia. Lisboa.

Stanford, W. B. ed. (reimp. 1987-1991). The Odyssey of Homer, I-II. London.

Adkins, A. W. H. (1972). "Homeric gods and the values of Homeric society", JHS 92: 1-19.

25 In Worthington 1994: 27. 
Buxton, R. G. A. (1982) Persuasion in greek tragedy - a study of Peitho. Cambridge. Desbordes, F. (1996). La rhétorique antique. L'art de persuader. Paris.

Griffin, J. (1986). "Homeric words and speakers", JHS 106: 36-57.

Guthrie, W. K. (1971). The Sophists. Cambridge.

Fortenbaugh, W. W. (1991). "Persuasion through character and the composition of Aristotle's rhetoric", Rheinisches Museum für Philologie 134. 2: 152-156.

Karp, A. J. (1977). "Homeric origins of ancient rhetoric", Arethusa 10. 2: 237-258.

Kennedy, G. (1963). The art of persuasion in Greece. Princeton.

Kessels, A. H. M. (1978). Studies on the dream in Greek literature. Utrecht.

Kullmann, W. (1985). "Gods and men in the Iliad and Odyssey". HSPh 89: 1-23.

Lévy, E. (1982). "Le rêve homérique”, Ktema 7: 23-41.

López Eire, A. (1987). "Sobre las origines de la oratória - I”, Minerva 1: 113-131.

López Eire (2002). Poéticas y retóricas griegas. Madrid.

Messer, W. S. (1918). The dream in Homer and Greek Tragedy. New York.

Pirenne-Delforge, V. (1991). "Le culte de la persuasion. Peitho en Grèce ancienne", Parole sacrée, parole profane - de la réligion à L'éloquence. (R. Kieffer - ed.) Luxembourg.

Rocha Pereira, M. H. (1997). "Os caminhos da persuasão na Ilíada", A retórica greco-latina e a sua perenidade I. Coimbra: 39-56.

Romilly, J. de (1988). Les grands Sophistes dans l'Athènes de Périclès. Paris.

Stensgaard, J. (2003). "Peithô in the Iliad: a matter of trust or obedience?", Classica et Mediaevalia 54: 41-79.

Solmsen, F. (1954). "The gift of speech in Homer and Hesiod", TAPhA 85: 1-15.

Worthington, I. ed. (1994). Persuasion: greek rhetoric in action. London and New York. 